\title{
Addition of antifungal skin bacteria to salamanders ameliorates the effects of chytridiomycosis
}

\author{
Reid N. Harris ${ }^{1, *}$, Antje Lauer ${ }^{1,3}$, Mary Alice Simon ${ }^{1,4}$, Jenifer L. Banning ${ }^{1,5}$, \\ Ross A. Alford ${ }^{2}$ \\ ${ }^{1}$ Department of Biology, MSC 7801, James Madison University, Harrisonburg, Virginia 22807, USA \\ ${ }^{2}$ School of Tropical Biology, James Cook University, Townsville, Queensland 4811, Australia \\ ${ }^{3}$ Present address: Department of Biology, California State University at Bakersfield, 9001 Stockdale Highway, \\ Bakersfield, California 93311, USA \\ ${ }^{4}$ Present address: School of Biology and Ecology, 5751 Murray Hall, University of Maine, Orono, Maine 04469, USA \\ ${ }^{5}$ Present address: Department of Biological Sciences, 2119 Derring Hall, Virginia Tech, Blacksburg, Virginia 24061, USA
}

\begin{abstract}
Chytridiomycosis, caused by the skin fungus Batrachochytrium dendrobatidis (Bd), has caused population declines of many amphibians in remote protected habitats. Progress has been made in understanding the pathogen's life cycle, documenting its devastating effects on individual amphibians and on populations, and understanding how and why disease outbreaks occur. No research has directly addressed the critical question of how to prevent declines and extinctions caused by outbreaks of the disease. We have identified a number of bacterial species of amphibian skin that inhibit $B d$ in vitro. Here, we demonstrate that a species of anti- $B d$ skin bacteria can be successfully added to skins of salamanders Plethodon cinereus, and that addition of this bacterium reduced the severity of a disease symptom in experimentally infected individuals. This is the first demonstration that manipulating the natural skin microbiota of an amphibian species can alter the pathogen's negative effects on infected amphibians and appears to be the first demonstration that an epibiotic manipulation of any wildlife species can lessen the effects of an emerging infectious disease. It suggests that probiotic or bio-augmentation manipulations of cutaneous microbiota could have the potential to reduce susceptibility of amphibians to the disease in nature. This is the first approach suggested that could slow or halt epidemic outbreaks and allow successful reintroductions of amphibian species that have become locally or globally extinct in the wild. Our results also suggest a mechanism for the association of climate change and the likelihood of chytridiomycosis outbreaks via the effects of the former on antifungal bacterial communities.
\end{abstract}

KEY WORDS: Batrachochytrium dendrobatidis - Amphibian declines · Beneficial bacteria $\cdot$ Probiotics · Chytridiomycosis

- Resale or republication not permitted without written consent of the publisher

\section{INTRODUCTION}

One-third of amphibian species are threatened with extinction (Stuart et al. 2004, Lips et al. 2006). Epidemic outbreaks of chytridiomycosis have caused many enigmatic amphibian declines, which occur in areas unaffected by habitat loss. The disease is caused by a chytrid fungus, Batrachochytrium dendrobatidis $(B d)$, that inhabits amphibian skin. In one well-docu- mented case it was demonstrated to be absent from a diverse tropical amphibian assemblage shortly before an epidemic outbreak that caused the local extinctions of many species (Lips et al. 2006). After such outbreaks, it persists in resistant species $(\mathrm{McD}$ onald et al. 2005). The timing and severity of epidemic outbreaks may be affected by recent changes in climate (Pounds et al. 2006), which could affect the pathogen, its amphibian hosts, or both. The only control methods 
proposed to date are quarantine, vaccination, spraying antifungal antibiotics into natural areas, and selective breeding. All of these are difficult to implement at the scale needed to control or prevent outbreaks in remote natural areas, and have thus far not proven effective or have not been implemented on a wide scale (Mendelson et al. 2006). In addition, the spraying of antifungal chemicals in the environment could negatively affect native fungi and associated plant life. The life cycle of the pathogen presents an opportunity to understand and potentially control it using an ecological approach.

We hypothesize that the composition of the microbial community on amphibian skin affects susceptibility to $B d$. The causative agent of chytridiomycosis has a life cycle that alternates between a flagellated zoospore that disperses and a zoosporangium that asexually produces zoospores (Longcore et al. 1999). When a zoospore comes into contact with amphibian skin, it encounters a diverse microbiota, which can be considered part of the innate immune system (Harris et al. 2006, Woodhams et al. 2007). Certain community profiles of the microbiota may be associated with pathogen resistance in amphibians, as in humans (Blaser 2006, Dethlefsen et al. 2006). We have identified a number of culturable species of bacteria from the skins of salamanders and frogs that produce antibiotics effective against $B d$ and other pathogenic fungi (Harris et al. 2006, Lauer et al. 2007, 2008, Woodhams et al. 2007). Environmental factors that alter the community profile of the skin microbiota toward species that are not antifungal might increase the likelihood of amphibians contracting chytridiomycosis and suffering from its effects. For example, climate change, pesticides, and antibiotics could alter the community composition of amphibian skin bacteria and leave them susceptible to disease outbreaks (Belden \& Harris 2007). Alternatively, adding or augmenting an anti- $B d$ species might lessen the effects of the disease, which include death and sub-lethal effects, such as weight loss (Davidson et al. 2007, Retallick \& Miera 2007). In the present study, we tested the hypothesis that the addition of antifungal skin bacteria to amphibians before exposure to $B d$ will enhance survival or lessen sub-lethal effects of the disease, such as weight loss.

\section{MATERIALS AND METHODS}

Field collection. Red-backed salamanders Plethodon cinereus were chosen for study because they are an extremely common amphibian; removing experimental individuals will not negatively affect population persistence. In addition, we have evidence from histological examination of shed skin that individuals do become infected with $B d$ and show clinical signs of infection, such as holding their limbs off the substrate for extended periods of time, weight loss, and mortality (authors' unpubl. data and see below). Salamanders as a group seem to be differently affected by $B d$ than anurans; however, there are reports of salamanders suffering the effects of $B d$ (e.g. 5 species of affected salamanders reported in Lips et al. 2006). Thus, information gleaned from a study of red-backed salamanders may be useful for conservation of other amphibian species, including anuran species.

Fifty individuals of the salamander Plethodon cinereus were collected in Rockingham County, Virginia, USA on 9 April 2006 and placed into individual sterile containers. Collectors cleaned their hands with antibiotic gel after capturing and handling a salamander. Salamanders were taken to the laboratory on 10 April 2006 and individuals were weighed in individual sterile Petri plates. Each salamander was handled with a unique pair of gloves. Salamanders were housed individually in sterile boxes with autoclaved filter paper, moistened with autoclaved medium (Provosoli medium, Wyngaard \& Chinnappa 1982) and placed at random into incubators held at $17^{\circ} \mathrm{C}$. Boxes were changed weekly and each salamander was fed a target number of 10 Drosophila flies, which were generally consumed quickly. Salamanders were fed in random order.

Experimental design. We randomly assigned 50 ind. to 1 of 4 treatments: (1) Medium: exposure to autoclaved Provosoli medium; (2) Bacteria: exposure to a species of skin bacteria, Pseudomonas reactans, previously shown to be anti-Bd in vitro, suspended in Provosoli medium; (3) $B d$ : exposure to $B d$ zoospores suspended in Provosoli medium; (4) Bacteria $+B d$ : exposure to $P$. reactans, followed by exposure $3 \mathrm{~d}$ later to $B d$ zoospores, both of which were suspended in Provosoli medium. Sample sizes were higher in the $B d$ and in the Bacteria + $B d$ treatments (n's $=20$ ) than in the 2 control treatments of Medium and Bacteria ( $n$ 's $=5$ ) because we wanted the highest statistical power for the comparison of most interest, i.e. does application of anti- $B d$ bacteria prevent the symptoms of $B d$ ? However, the 2 control treatments did not differ in proportion of weight lost and were pooled for statistical analysis.

Microbe sampling. All individuals were swabbed 10 times on lateral and ventral surfaces on 10 April 2006 with rayon swabs (Medical Wire \& Equipment) before application of experimental treatments for an assay of $B d$ occurrence and swabbed again for a culture independent assay of skin bacteria diversity (denaturing gradient gel electrophoresis, or DGGE; Lauer et al. 2007, 2008). This date was considered Day 1 of the experiment. Taqman PCR was conducted on skin swabs using the methods of Boyle et al. (2004) to assay for $B d$ occurrence on all salamanders before the experiment started and $14 \mathrm{~d}$ after individuals in the $B d$ and 
Bacteria $+B d$ treatment were exposed to $B d$. Swabs were also done on Day 10 for DGGE analysis to see if inoculated bacteria were evident on the skin in the Bacteria $+B d$ treatment.

Inoculation with anti-Bd skin bacteria. Salamanders in the Bacteria and Bacteria $+B d$ treatments were bathed in a solution containing Pseudomonas reactans obtained from the skin of Plethodon cinereus. Two surveys of $P$. cinereus in the same area as those used in this experiment revealed that between 22 and $54 \%$ of individuals had Pseudomonas sp. on their skin. A pure culture of $P$. reactans was incubated for $2 \mathrm{~d}$ in $1 \%$ tryptone broth. Cells were harvested by centrifugation at $4500 \times g$ for $10 \mathrm{~min}$. Cells were re-suspended in Provosoli medium and centrifuged 3 times to remove any metabolites in the medium and then re-suspended a fourth time in medium. Salamanders were placed in $50 \mathrm{ml}$ Falcon tubes along with $5 \mathrm{ml}$ solution $(3.2 \times$ $10^{9}$ cells $\mathrm{ml}^{-1}$, obtained by serial dilutions) for $2 \mathrm{~h}$ in $50 \mathrm{ml}$ Falcon tubes. Tubes were rotated every $30 \mathrm{~min}$. Salamanders in the other treatments were exposed to medium alone.

DGGE is a method to characterize culturable and unculturable bacterial species diversity and was used to detect whether Pseudomonas reactans was successfully inoculated onto salamander skins. Salamanders were rinsed twice to remove transient bacteria (Lauer et al. 2007) and swabbed as described above. Individuals were swabbed before and after inoculation with $P$. reactans. Swabs were stored on ice and then frozen $\left(-20^{\circ} \mathrm{C}\right)$ for DNA-extraction of the cutaneous bacterial microbiota. DNA extracted from a pure culture of $P$. reactans was also used in the DGGE analysis to determine the band location of $P$. reactans on the gel. DGGE protocols that we used are presented in detail in Lauer et al. (2007).

Exposure to $\boldsymbol{B d}$. A salamander randomly assigned to receive $B d$ in the $B d$ treatment and in the Bacteria $+B d$ treatment was confined to a $50 \mathrm{ml}$ Falcon tube with a $2.79 \times 10^{6}$ zoospores $5 \mathrm{ml}^{-1}$ solution for $4 \mathrm{~h}$, which was rolled every half hour, and then the zoospore solution and the salamander were transferred to a small hard plastic box for another $20 \mathrm{~h}$. Exposure to Bd occurred $3 \mathrm{~d}$ after individuals in the Bacteria $+B d$ treatment were inoculated with Pseudomonas reactans. The $B d$ strain used was JEL 215. Cultures were maintained in $1 \%$ tryptone broth at $23^{\circ} \mathrm{C}$ and transferred weekly until the salamanders were ready for exposure. Zoospores for exposure were prepared by growing an approximately 1 wk old broth culture on $1 \%$ tryptone plates containing $1 \%$ agar. After approximately $4 \mathrm{~d}$ (maximum zoospore production), plates were flooded with $3 \mathrm{ml}$ Provosoli medium. Twenty minutes later, the plates were flooded again and left to sit for another $20 \mathrm{~min}$. The resulting liquid was then filtered through a UV-sterilized SpectraMesh nylon $20 \mu \mathrm{m}$ filter (Spectrum Medical Industries) and zoospore density was determined by a hemacytometer. All individuals not assigned to receive $B d$ were exposed to Provosoli medium. The experiment was ended on Day 46, when all individuals were weighed, killed with MS-222 and stored in $10 \%$ buffered formalin. Thus, no individuals with $B d$ infections were released into nature.

Statistical analysis. Analysis of the variable 'number of individuals infected with $B d$ ' was conducted using PROC CATMOD in the statistical software SAS (version 9). Analyses of the variables 'number of zoospore equivalents' and 'proportional weight change' were conducted using PROC GLM. A posteriori tests were made using the Bonferroni correction. Means are presented $\pm 1 \mathrm{SE}$.

\section{RESULTS}

We detected a very low level of $B d$ (1 zoospore) on 1 ind. when all 50 ind. were swabbed before any experimental treatments were applied. This individual landed in the Bacteria $+B d$ treatment by random assignment. An analysis of DGGE gels showed that 4 ind. randomly assigned to the Bacteria $+B d$ group had a band that migrated to the same place as did the band from a pure culture of Pseudomonas reactans, suggesting that they had this bacterial species on their skin before inoculation. Ten days after inoculation with $P$. reactans, these 4 ind. still had this bacterial species on their skin and the band associated with it tended to be stronger. Twelve individuals that initially lacked $P$. reactans now had it on their skin, and gels of 2 salamanders were not interpretable before or after inoculation. Thus, 16 of 18 ind. (89\%) in the Bacteria $+B d$ group had $P$. reactans on their skin and we were successful in placing anti-Bd bacteria of amphibian skin.

We compared persistence of the pathogen and changes in body mass between animals in the $B d$ and Bacteria $+B d$ treatments. Addition of Pseudomonas reactans did not reduce the proportion of individuals infected at Day 14 (Table 1; Fisher's Exact Test; p = 0.300). These estimates are based on real-time Taq-

Table 1. Batrachochytrium dendrobatidis $(B d)$ infecting Plethodon cenereus. Number of individuals with and without detectable $B d$ zoospores as detected by Real-time Taqman PCR on Day 14 after exposure to $B d$

\begin{tabular}{|lcc|}
\hline & Exposed to $B d$ & $\begin{array}{c}\text { Exposed to } \\
\text { Bacteria }+B d\end{array}$ \\
\hline$B d$ detected & 12 & 16 \\
$B d$ not detected & 8 & 4 \\
\hline
\end{tabular}


man PCR estimates of zoospore number, however we also examined shed skin stained with $0.01 \%$ Congo red dye from individuals shedding their skin in the groups exposed to $B d$ and these skins were infected with $B d$ zoosporangia. Average number of zoospore equivalents on infected individuals did not differ between $B d$ and Bacteria $+B d$ treatments $(B d$ treatment: $9.75 \pm 5.6, \mathrm{n}=12$; Bacteria $+B d$ treatment: $6.19 \pm$ $1.9, \mathrm{n}=16 ; t=0.667, \mathrm{df}=26, \mathrm{p}=0.509$ ).

At the experiment's conclusion on Day 46, salamanders exposed to $B d$ and not Pseudomonas reactans lost twice as large a proportion of their initial body mass as those first treated with $P$. reactans (Fig. $1 ; F_{1,37}=10.28$; $\mathrm{p}=0.006$ with Bonferroni correction). Mass lost by individuals in the Bacteria $+B d$ treatment was similar to mass lost by the 10 control individuals exposed to $P$. reactans alone or exposed to medium alone (Fig. 1; $F_{1,28}=0.95 ; \mathrm{p}=0.347$ ). Some individuals in the $B d$ and Bacteria $+B d$ treatments were not infected with $B d$ at Day 14 based on PCR estimates of zoospore number. Those not infected in the $B d$ and Bacteria $+B d$ treatments did not differ in proportion of mass lost $\left(F_{1,9}=\right.$ $0.29 ; \mathrm{p}=0.603)$. However, those infected in the $B d$ treatment lost significantly more mass as a proportion of initial mass than did infected individuals in the Bacteria $+B d$ treatment $\left(F_{1,26}=10.53 ; \mathrm{p}=0.006\right.$ with Bonferroni correction).

\section{DISCUSSION}

Our results indicate that the community composition of the cutaneous microbiota had a strong effect on the morbidity caused by chytridiomycosis. Our DGGE gels indicated that we successfully established the bacteria Pseudomonas reactans on salamanders treated with it

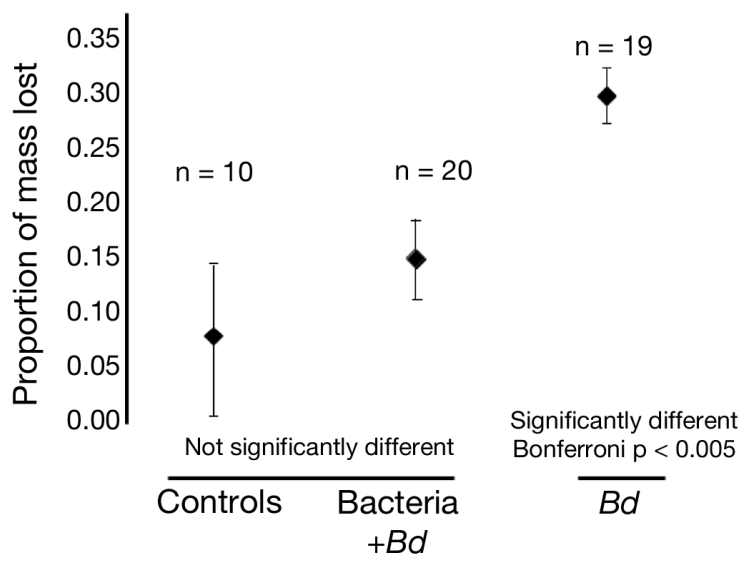

Fig. 1. The addition of Pseudomonas reactans to Plethodon cinereus prevented weight loss caused by Batrachochytrium dendrobatidis (Bd). Mass lost as a proportion of initial mass for the $B d$, Bacteria $+B d$, and the pooled control treatments (Medium and Bacteria) only once. The addition of $P$. reactans to individuals infected with $B d$ prevented the dramatic weight loss seen in infected salamanders not exposed to the anti$B d$ bacteria. Weight loss has been demonstrated as a sub-lethal effect of chytridiomycosis in recent studies by Retallick \& Miera (2007) and Davidson et al. (2007). Based on detection of $B d$ on the skin by PCR and by histological examination of shed skin, we conclude that individuals in the $B d$ treatment were infected with $B d$ and that they lost more weight than control individuals as a result of their infection. Control individuals in our study also lost weight, suggesting that our diet of fruit flies did not allow growth; nonetheless, individuals in the $B d$ treatment lost twice as much weight as those first treated with anti- $B d$ bacteria and this difference was statistically significant. The similar estimates of zoospore equivalents from $B d$ and Bacteria $+B d$ groups on Day 14 suggest bacterial addition inhibited the negative effects of $B d$ on individual salamanders without necessarily killing the $B d$, perhaps by making $B d$ moribund and therefore less effective in altering an amphibian's epidermal functions (Voyles et al. 2007). Alternatively, $B d$ abundance in the Bacteria $+B d$ treatment may have declined relative to that in the $B d$ treatment by the end of the experiment on Day 46. We have shown that skin bacteria of Plethodon cinereus produce anti- $B d$ metabolites, so it is a reasonable hypothesis that added skin bacteria killed or attenuated $B d$ (Brucker et al. 2008a,b). The experimental treatments did not affect survival, which suggests that this salamander species is not as vulnerable to the effects of chytridiomycosis as many other anuran and caudate species (Lips et al. 2006) or that the strain of $B d$ used was not virulent enough to cause mortality of this salamander species.

The strict randomization in this experiment, such as random assignment of individuals to treatments and treatments to physical locations within the laboratory incubators, strongly suggests that statistically significant differences in weight loss were caused by treatment differences. Therefore, we conclude that interactions between amphibians' cutaneous bacteria and $\mathrm{Bd}$ were important in affecting symptomatology (weight loss) in individuals and probably in determining whether a population of amphibians will persist with the pathogen. In future studies of this type, assaying the effect of antifungal skin bacteria on skin histopathology per se will be important in determining the nature of the interactions between bacteria and $B d$. Anurans appear to be more affected as a group by chytridiomycosis than salamanders (Lips et al. 2006), so extending the type of experimental study done here with frog species will be important. In the Sierra Nevada mountains, a population of the frog Rana muscosa that persists with $B d$ had a higher proportion of 
individuals with at least 1 culturable anti- $B d$ bacterial isolate on their skin than did a population that dramatically declined once $B d$ arrived (Woodhams et al. 2007). While the study was correlative, it also suggests a role of anti- $B d$ skin bacteria in combating chytridiomycosis in an anuran species.

Environmental change, such as climate change, habitat alteration, or increased levels of toxicants, may generally affect the species composition of microbial symbionts (Reshef et al. 2006) by altering microbial diversity available for colonization of the host (Fraterrigo et al. 2006, Kao-Kniffin \& Balser 2007, Lipson 2007). Environmental changes that lead to an alteration of the antifungal component of amphibian's cutaneous microbiota can increase the likelihood of chytridiomycosis outbreaks. The relationship found between climate change and an outbreak of chytridiomycosis in Costa Rica (Pounds et al. 2006) may have been due to changes in amphibians' cutaneous microbiota that allowed $B d$ to more effectively colonize and reproduce.

The addition or encouragement of anti-Bd skin bacteria to amphibians' natural resident cutaneous microbiota may be a useful tool in managing its effects at levels from individuals to populations and species assemblages. This might be accomplished without introducing exotic bacteria, simply by augmenting the density of anti- $B d$ skin bacteria that already occur on species at risk or by increasing the proportion of individuals in a population with anti-Bd skin bacteria (Woodhams et al. 2007). Outbreaks of the pathogen may be predictable in some parts of the world (Lips et al. 2006), so probiotic applications of anti- $B d$ skin bacteria could be focused in areas of predicted outbreaks. Of course, the demonstration of a positive effect on survival of infected amphibians, tests on more species, including anuran species, and additional environmental testing in more complex environments are needed before implementation can be considered. However, the supplementation of beneficial bacteria is already widely done for soil improvement and appears to be safe and effective (Haas \& Dégafo 2005). Recent progress in the use of 'bacterial replacement therapy' in humans suggests that alternations of the bacterial community can limit or prevent disease (Tagg \& Dierksen 2003). Manipulation of amphibians' cutaneous microbiota is currently the only suggested approach that offers the potential of slowing or halting epidemic outbreaks in the field and that can allow successful reintroductions of species that have become locally or globally extinct in the wild. We urge further study of the efficacy of bacterial supplementation in halting the devastating effects of chytridiomycosis on amphibian populations.
Acknowledgments. We thank I. Knight, G. Wyngaard, and B. Lam for helpful comments. J. Longcore provided the $B d$ isolate that we used. Animals were collected by permit from the Virginia Division of Game and Inland Fisheries. Our animal care protocol was approved by JMU's Animal Care and Use Committee. This work was supported by NSF grant 0640373 to R.N.H.

\section{LITERATURE CITED}

Belden LK, Harris RN (2007) Infectious diseases in wildlife: the community ecology context. Front Ecol Environ 5: $533-539$

Blaser MJ (2006) Who are we? Indigenous microbes and the ecology of human diseases. EMBO Rep 7:956-960

Boyle DG, Boyle DB, Olsen V, Morgan JAT, Hyatt AD (2004) Rapid quantitative detection of chytridiomycosis (Batrachochytrium dendrobatidis) in amphibian samples using real-time Taqman PCR assay. Dis Aquat Org 60:141-148

Brucker RM, Baylor CM, Walters RL, Lauer A, Harris RN, Minbiole KPC (2008a) The identification of 2,4-diacetylphloroglucinol as an antifungal metabolite produced by cutaneous bacteria of the salamander Plethodon cinereus. J Chem Ecol 34:39-43

Brucker R, Harris RN, Schwantes CR, Gallaher TN, Flaherty DC, Lam BA, Minbiole KPC (2008b) Amphibian chemical defense: antifungal metabolites of the microsymbiont Janthinobacterium lividum on the salamander Plethodon cinereus. J Chem Ecol 34:1422-1429

Davidson C, Benard MF, Shaffer HB, Parker JM, O'Leary C, Conlon JM, Rollins-Smith LA (2007) Effects of chytrid and carbaryl exposure on survival, growth and skin peptide defenses in foothill yellow-legged frogs. Environ Sci Technol 41:1771-1776

Dethlefsen L, Eckburg PB, Bik EM, Relman DA (2006) Assembly of the human intestinal microbiota. Trends Ecol Evol 21:517-523

- Fraterrigo JM, Balser TC, Turner MG (2006) Microbial community variation and its relationship with nitrogen mineralization in historically altered forests. Ecology 87: 570-579

> Haas D, Dégafo G (2005) Biological control of soil-borne pathogens by fluorescent pseudomonads. Nat Rev Microbiol 3:307-319

> Harris RN, James TY, Lauer A, Simon MA, Patel A (2006) the amphibian pathogen Batrachochytrium dendrobatidis is inhibited by the cutaneous bacteria of amphibian species. EcoHealth 3:53-56

Kao-Kniffin J, Balser TC (2007) Elevated $\mathrm{CO}_{2}$ differentially alters belowground plant and soil microbial community structure in reed canary grass-invaded experimental wetlands. Soil Biol Biochem 39:517-525

Lauer A Simon MA, Banning JL, Lam B, Harris RN (2008) Diversity of cutaneous bacteria with antifungal activity isolated from female four-toed salamanders. ISME J 2: 145-157

Lauer A, Simon MA, Banning JL, Andre E, Duncan K, Harris RN (2007) Common cutaneous bacteria from the eastern red-backed salamander can inhibit pathogenic fungi. Copeia 2007:630-640

- Lips KR, Brem F, Brenes R, Reeve JD and others (2006) Emerging infectious disease and the loss of biodiversity in a Neotropical amphibian community. Proc Natl Acad Sci USA 103:3165-3170

> Lipson DA (2007) Relationships between temperature responses and bacterial community structure along sea- 
sonal and altitudinal gradients. FEMS Microbiol Ecol 59: $418-427$

Longcore JE, Pressier AP, Nichols DK (1999) Batrachochytrium dendrobatidis gen. et sp. nov., a chytrid pathogenic to amphibians. Mycologia 91:219-227

McDonald KR, Méndez D, Müller R, Freeman AB, Speare R (2005) Decline in the prevalence of chytridiomycosis in frog populations in North Queensland, Australia. Pac Conserv Biol 11:114-120

Mendelson JR III, Lips KR, Gagliardo RW, Rabb GB and others (2006) Confronting amphibian declines and extinctions. Science 313:48

Pounds JA, Bustamante MR, Coloma LA, Consuegra JA and others (2006) Widespread amphibian extinctions from epidemic disease driven by global warming. Nature 439: 161-167

Reshef L, Koren O, Loya Y, Zilber-Rosenberg I, Rosenberg E (2006) The coral probiotic hypothesis. Environ Microbiol 8:2068-2073

Retallick RWR, Miera V (2007) Strain differences in the amphibian chytrid Batrachochytrium dendrobatidis and

Editorial responsibility: Alex Hyatt,

Geelong, Victoria, Australia non-permanent, sub-lethal effects of infection. Dis Aquat Org 75:201-207

Stuart SN, Chanson JS, Cox NA, Young BE, Rodrigues ASL, Fischman DL, Waller RW (2004) Status and trends of amphibian declines and extinctions wordwide. Science 306:1783-1786

Tagg JR, Dierksen KP (2003) Bacterial replacement therapy: adapting 'germ warfare' to infection prevention. Trends Biotechnol 21:217-223

Voyles J, Berger L, Young S, Speare R and others (2007) Electrolyte depletion and osmotic imbalance in amphibians with chytridiomycosis. Dis Aquat Org 77:113-118

Woodhams DC, Vredenburg VT, Stice MJ, Simon MA and others (2007) Symbiotic bacteria contribute to innate immune defenses of the threatened mountain yellow-legged frog, Rana muscosa. Biol Conserv 138: 390-398

Wyngaard GA, Chinnappa CC (1982) General biology and cytology of Cyclopoids. In: Harrison FW, Cowden RR (eds) Developmental biology of freshwater invertebrates. A. R. Liss, New York, p 485-533

Submitted: February 5, 2008; Accepted: October 27, 2008 Proofs received from author(s): January 21, 2009 